\title{
Molecular genetics of medullary thyroid carcinoma: the quest for novel therapeutic targets
}

\author{
Aniello Cerrato, Valentina De Falco and Massimo Santoro \\ Istituto di Endocrinologia ed Oncologia Sperimentale CNR c/o Dipartimento di Biologia e Patologia Cellulare e Molecolare, 'L. Califano', \\ Università Federico II di Napoli, via S. Pansini 5, 80131 Naples, Italy \\ (Correspondence should be addressed to M Santoro; Email: masantor@unina.it)
}

\begin{abstract}
Medullary thyroid carcinoma (MTC) is a rare tumour arising from neural crest-derived parafollicular C-cells. Metastatic MTC patients are incurable because the cancer does not respond to radiotherapy or chemotherapy. The REarranged during Transfection (RET) proto-oncogene plays a key role in the development of MTC. However, one-half of the sporadic MTC do not carry RET mutations. Mice models and early evidence obtained in human samples suggest that other genes, including those encoding components of the RB1 (retinoblastoma) and TP53 tumour-suppressor pathways, may be involved in MTC formation. Here, we review the data on the involvement of genes acting in the RET and RB1/TP53 pathways in MTC. Understanding genetic lesions that occur in MTC is a prerequisite to identifying molecular therapeutic targets in MTC and in improving the efficacy of RET-targeted therapies.
\end{abstract}

Journal of Molecular Endocrinology (2009) 43, 143-155

\section{Medullary thyroid carcinoma: a genetic overview}

Medullary thyroid carcinoma (MTC) arises from calcitonin-producing neural crest-derived parafollicular (C) cells of the thyroid. MTC accounts for $5-8 \%$ of all thyroid cancers (Matias-Guiu et al. 2004, Schlumberger et al. 2008). MTC is sporadic in about $75 \%$ of the cases; in the remaining cases, it occurs as a component of the autosomal dominant familial multiple endocrine neoplasia type 2 (MEN 2) syndrome. MEN 2, first described by Sipple (1961), includes three disorders: MEN 2A; MEN 2B; and familial MTC (FMTC; Marx 2005, Elisei et al. 2007, Zbuk \& Eng 2007). MEN 2-associated MTC is bilateral and multicentric, and it is usually preceded by multifocal C-cell hyperplasia (CCH; Gagel \& Marx 2003). REarranged during Transfection (RET) is mutated in roughly $50 \%$ of sporadic MTC and in more than $95 \%$ of MEN 2 families.

In FMTC, although the germ line RET mutation is present in all somatic cells of the affected individual, tumours are monoclonal, which suggests that other genetic alterations must occur at the somatic level and act in concert with RET mutations for the tumour to develop (Gagel \& Marx 2003). Moreover, a few MEN 2 families negative for $R E T$ mutations have been described, suggesting the existence of additional loci predisposing to MEN 2 (Montero-Conde et al. 2007).
Finally, about $50 \%$ of sporadic MTC do not carry RET mutations. Whether another frequently mutated gene or multiple low-frequency mutated genes occur in RET wild-type MTC samples is unknown.

In MEN 2, MTC is associated in about $50 \%$ of cases to pheochromocytoma (MEN 2A and 2B), and in 10-35\% of cases to parathyroid hyperplasia or adenoma (MEN 2A; Gagel \& Marx 2003). This suggests that MTC shares pathogenetic mechanisms with pheochromocytomas and parathyroid tumours. However, MTC is not a phenotype of non-MEN 2 familial forms of parathyroid tumours or pheochromocytomas (Gagel \& Marx 2003, Marx 2005, Zbuk \& Eng 2007). Accordingly, Prad1/ Ccnd1, Men 1 and Hprt2 genes (associated to non-MEN 2 forms of parathyroid tumours; Ferris \& Simental 2004) and $V h l, N f 1$ and succinate dehydrogenase subunits B, C and D $(S d h B, S d h C$ and $S d h D$; associated to non-MEN 2 forms of pheochromocytomas; Maher \& Eng 2002, Kaelin 2008) do not seem to be mutated in MTC. $S d h B$, $C$ and $D$ were not found to be mutated in sporadic MTC (Lima et al. 2003, Cascon et al. 2005, Montani et al. 2005), although germ line $S d h B$ and $S d h D$ variants were over-represented in MTC samples with respect to healthy individuals (Sobrinho-Simões et al. 2008). One mutation and three monoallelic deletions were found in the $V h l$ gene in five familial $R E T$ mutant MTC samples, suggesting cooperation of Ret gain with Vhlloss in MTC formation (Koch et al. 2006). Intriguingly, Vhl, 
$N f 1$ and $S d h$ gene products collaborate with RET in a common signalling pathway involved in controlling EglN3 prolyl hydroxylase-mediated neuronal cell apoptosis. In this pathway, RET (gain-of-function) and NF1 and VHL (loss-of-function) mutations lead to increased JunB transcription factor, which, in turn, blunts the expression of EglN3, thereby leading to inappropriate cell survival and tumourigenesis (Kaelin 2008). Loss of $\mathrm{SDH}$ activity results in higher succinate levels; this in turn triggers the survival pathway because EglN3 is feedback-inhibited by succinate. Finally, the recently discovered $K I F 1 B$ tumour suppressor, which maps in a chromosomal region (1p36) frequently deleted in MTC (see below), is required for EglN3 pro-apoptotic activity (Kaelin 2008). Thus, even if not frequently mutated, these proteins should be functionally analyzed in relation to MTC formation.

In the following sections we focus on genes acting in the RET (Fig. 1) and RB/TP53 (Fig. 2) pathways.

\section{RET signalling pathway in MTC}

\section{The RET gene in FMTC and sporadic MTC}

The RET gene has been extensively reviewed elsewhere (Kodama et al. 2005, Kondo et al. 2006, Santoro \& Carlomagno 2006, Asai et al. 2006b). Therefore, here we

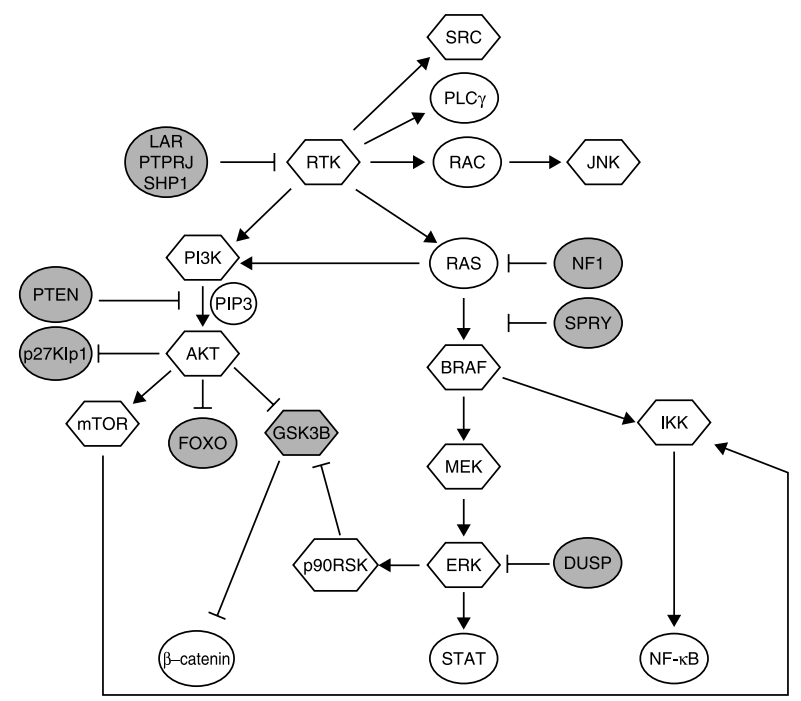

Figure 1 Schematic representation of the RTK (receptor tyrosine kinase) signalling pathways. Potential oncoproteins are in white, whereas tumour suppressors are in grey, $\square=$ kinases. It should be noted that only some signalling effectors are represented. RAS and AKT proteins have several effectors (like RALGDS for RAS) in addition to those represented in the figure. In addition, only some of the interactions that occur among the various proteins are represented. For instance, RTKs like RET are known to directly phosphorylate beta-catenin and STAT, besides activating them through RAS and AKT. Moreover, AKT may directly phosphorylate IKK proteins.

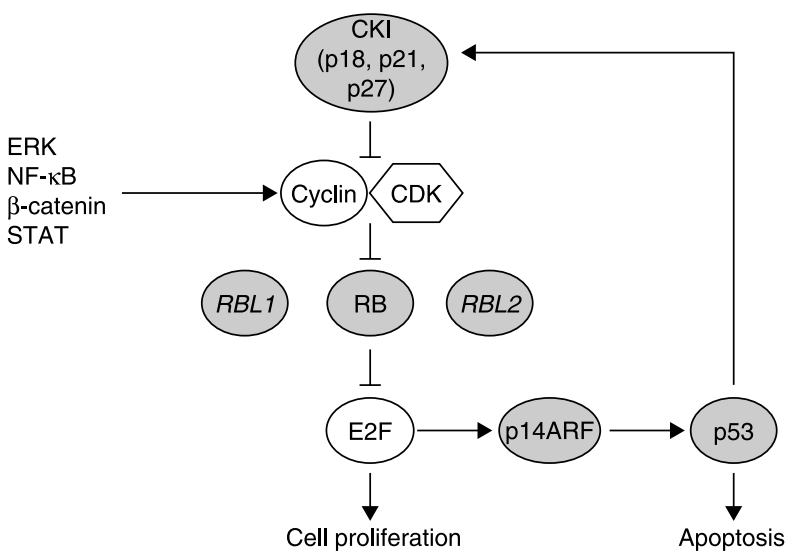

Figure 2 Schematic representation of RB and p53 signalling pathways leading to cell proliferation arrest and apoptosis.

Potential oncoproteins are in white, whereas tumour suppressors are in grey, $\square$ = kinases.

will summarize a few key points. The RET protein product is a single pass transmembrane receptor with an intracellular tyrosine kinase domain (RTK= receptor tyrosine kinase) that binds glial-derived neurotrophic factor (GDNF) ligands. Ret was initially described as a bona fide proto-oncogene because it is activated by chromosomal aberrations in papillary thyroid carcinoma (PTC; Kondo et al. 2006, Santoro \& Carlomagno 2006). Subsequently, it was found that the germ line point mutations in Ret causes MEN 2 syndrome, and similar mutations at the somatic level are the most common genetic alterations identified so far in sporadic MTC (Gagel \& Marx 2003, Kouvaraki et al. 2005, Marx 2005, Zbuk \& Eng 2007). Most MEN 2B patients (95\% of cases) carry the M918T-mutation in $R E T$; the remaining fraction harbours the A883F substitution or other rare mutations. In $98 \%$ of MEN 2A, the mutations affect one of the five cysteines in the extracellular cysteine-rich domain of RET. In FMTC, mutations affect either the extracellular cysteines or the intracellular domain of RET (Niccoli-Sire et al. 2001, Gagel \& Marx 2003, Kouvaraki et al. 2005, Marx 2005, Elisei et al. 2007, Zbuk \& Eng 2007). The genotypephenotype correlation between the type of Ret mutation and penetrance and expressivity of the disease further supports the prime role exerted by Ret mutations in FMTC (Machens \& Dralle 2007). Thanks to this close correlation between a specific genetic lesion and cancer occurrence, MEN 2 is the best example in oncology of the efficacy of molecular diagnosis in mainstream clinical management. In fact, early thyroidectomy in Ret mutation carriers significantly improved their prognosis (Brandi et al. 2001, Gagel \& Marx 2003, Skinner et al. 2005, Machens \& Dralle 2007). Sporadic MTC, particularly more aggressive cases, also frequently (30-50\% of cases) feature the M918T-RET mutation (Elisei et al. 2007, 2008). Finally, susceptibility to 
sporadic MTC could be influenced by the RET polymorphisms G691S/S904S (Robledo et al. 2003, Elisei et al. 2004, Cebrian et al. 2005, Lesueur et al. 2006), however, these findings require confirmation on larger casistics (Weber \& Eng 2005).

As discussed above, secondary genetic alterations at somatic level must act in concert with mutations in Ret for MTC to develop (Gagel \& Marx 2003). Probably, only a small number of secondary genetic events are required in MEN 2B mutation carriers because, in these patients, the disease develops in the first few months of their life. A secondary genetic hit may target the Ret gene itself, either through duplication of the mutant allele or loss of the wild-type allele (Huang et al. 2003). Additional hits may involve chromosome deletion and amplification events, such as the deletion in chromosome lp (Mathew et al. 1987, Khosla et al. 1991, Mulligan et al. 1993, Marsh et al. 2003, Ye et al. 2008).

MTC-associated Ret-mutations convert Ret into a dominantly transforming oncogene. Extracellular cysteine MEN 2A/FMTC RET-mutants exert constitutive kinase activity consequent to ligand-independent homodimerization. In the case of mutation M918T, constitutive RET activation probably results from disruption of an auto-inhibited head-to-tail RET TK homodimer (Knowles et al. 2006).

Transgenic mouse models demonstrated that RET oncogenes are able to drive MTC formation. Mice expressing RET-C634R or RET-M918T, but not wild-type $R E T$, under the control of the calcitonin gene promoter developed MTC (Michiels et al. 1997, Acton et al. 2000). Also transgenic mice carrying RET-C634R under the control of a ubiquitous viral promoter developed MTC, suggesting that murine C-cells are highly susceptible to RET-mediated transformation (Kawai et al. 2000). However, the knock-in of the M918T mutation into mouse endogenous Ret gene caused CCH but not MTC, suggesting that, in the background of a normally expressed Ret-mutant allele, the accumulation of secondary genetic alterations is required for development of MTC (Smith-Hicks et al. 2000). Genetic background strongly affected the MTC phenotype in transgenic mice, with tumour penetrance varying from $0 \%$ in $\mathrm{FVB} / \mathrm{N}$ to $98 \%$ in $\mathrm{CBA} / \mathrm{ca}$ mice, which suggests that the genetic modifiers greatly affect RET-driven MTC risk (Cranston \& Ponder 2003).

RET knock-down by dominant-negative mutants, ribozymes or RNAi impaired proliferation of RET-mutant MTC cell lines (Parthasarathy et al. 1999, Drosten et al. 2004). Taken together, these studies strongly implicated RET in the formation and maintenance of a subset of MTC, and provided the conceptual framework for the use of RET kinase inhibitory compounds in MTC clinical trials (Wells \& Nevins 2004, Castellone et al. 2008, Schlumberger et al. 2008, Sherman 2008).

\section{RET signalling cascade}

Genetic screenings in model organisms have shown that the same phenotype can arise from alterations in any of several genes acting epistatically in common signalling cascades. Similarly, although the number of potential cancer driver genes is large, this probably reflects changes in only a few pathways. For instance, a systematic cancer genome analysis recently revealed that many mutations in colon and breast cancer cluster in genes acting in few signalling cascades (Wood et al. 2007, Sjöblom 2008). Thus, if gain-of-function RET-mutations are associated with human MTC, it is equally plausible that mutations in the genes encoding co-receptors/ligands that trigger RET activation or signalling effectors that mediate RET intracellular effects play a role in MTC. An important proof of this concept was provided by genetic analysis of PTC, another thyroid tumour type, in which $R E T$ is implicated. Indeed, it was found that most PTC cases that are negative for RET (RET/ PTC) rearrangements harbour either mutations of $B R A F$, an effector of the RET-initiated extracellularsignal regulated kinase (ERK) signalling cascade or, less frequently, in NTRK1, another growth factor receptor (Fig. 1; Fagin 2005, Kondo et al. 2006, Pierotti \& Greco 2006).

RET is activated through the binding of four GDNF family ligands (GFL) GDNF, neurturin (NRTN), artemin (ARTN), persephin (PSPN) together with the four corresponding membrane co-receptors (GFR $\alpha 1,2,3$ and 4; Airaksinen \& Saarma 2002). GFR $\alpha 4$, in particular, is expressed in normal C-cells and the corresponding ligand, PSPN, is required for calcitonin production by C-cells (Lindahl et al. 2001, Lindfors et al. 2006). No somatic mutation in any of the GFL/GFRA encoding genes has been reported in MTC (Marsh et al. 1997, Borrego et al. 1998), although GFL/GFRA genes map in chromosomal regions where allelic imbalances were detected in MTC (Marsh et al. 2003). Polymorphic variants of GFL/GFRA genes, particularly GFRA1 in familial (Gimm et al. 2001a, Lesueur et al. 2006) and GFRA4 in sporadic (Cebrian et al. 2005, Vanhorne et al. 2005, Ruiz-Llorente et al. 2007) MTC cases, have been reported.

Once activated, RET transmits mitogenic, survival and motogenic signals (Kodama et al. 2005, Asai et al. 2006b, Santoro \& Carlomagno 2006). Two major signalling cascades, namely RAS and phosphatidylinositol 3-kinase (PI3K), are triggered by RET (Fig. 1). In turn, RAS and PI3K contribute to the activation of many signalling effectors and, as described below, they concur to the activation of nuclear factor- $\kappa \mathrm{B}(\mathrm{NF}-\kappa \mathrm{B})$, signal transducer and activator of transcription (STAT) and betacatenin. Other signalling effectors, namely SRC (Encinas et al. 2004, Iavarone et al. 2006), phospholipase 


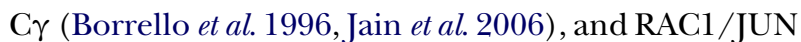
$\mathrm{NH}$ (2)-terminal kinase (JNK; Chiariello et al. 1998, Fukuda et al. 2002, Asai et al. 2006a) are activated by RET (Fig. 1). In principle, gain-of-function of these pathways may contribute to MTC. Moreover, negative regulators of RET signalling have also been identified and, in principle, their loss-of-function may contribute to MTC formation (Fig. 1).

Hereafter, we focus on the RET pathways that have been more extensively studied in MTC. Components of these pathways may be exploited as molecular targets for MTC treatment.

\section{RAS pathway}

Growth-factor binding to cell surface RTKs creates docking sites for adaptor molecules that activate guanine nucleotide-exchange factors, which in turn favours GTP binding to RAS small G-proteins (KRAS, HRAS and NRAS; Schubbert et al. 2007). Intrinsic RASGTPase activity terminates signalling, a reaction that is accelerated thousands of fold by GTPase-activating proteins such as neurofibromin (NF1; Fig. 1; Schubbert et al. 2007). Once activated, RAS stimulates numerous intracellular transducers, including RAF, PI3K and Ral guanine nucleotide-dissociation stimulator, to regulate proliferation, survival and differentiation (Fig. 1; Halilovic \& Solit 2008). The RAS-RAF-MEK-ERK cascade is the best characterized RAS-effector pathway. There are three RAF serine/threonine kinases (ARAF, BRAF and CRAF) that activate the MEK (MAP2K1/ MAP2K2)-ERK (MAPK3/MAPK1) kinase cascade. ERK, in turn, stimulates gene transcription by directly phosphorylating transcription factors or by targeting intracellular kinases like p90RSK (Fig. 1; Schubbert et al. 2007). Negative regulators attenuate RAS signalling at various levels of the signalling cascade (Fig. 1; see below).

RAS genes are most commonly activated by point mutations in cancer. Alternatively, the RAS pathway can be triggered indirectly by loss of the negative regulator $N F 1$, by upstream activation of cell surface RTKs or PTPN11 (which encodes the Src homology-2containing protein tyrosine phosphatases-2 (SHP-2)) or by downstream activation of RAS signalling effectors (Fig. 1; Wellbrock et al. 2004, Halilovic \& Solit 2008). This paradigm applies to thyroid carcinoma of follicular cell lineage, where RET gene rearrangements are prevalent in PTC, RAS-mutations in follicular carcinoma and in follicular-variant PTC, and BRAFmutations in PTC and anaplastic carcinoma (Kondo et al. 2006). Sequencing analysis of all three $R A S$ family members did not reveal any mutation in about 30 MTC samples (Moley et al. 1991, Horie et al. 1995, Bockhorn et al. 2000). Similarly, no BRAF-mutation was found in 65 MTC samples (Xing 2005). Taken together, these findings excluded that $R A S / B R A F$ gene mutations exert a prominent role in MTC formation. However, a recent study led to a different conclusion by showing $41 \%$ KRAS-mutations and 68\% BRAF-mutations in MTC samples (Goutas et al. 2008).

The degree and duration of activation dictate the final biological outcome of RAS signalling. For example, in PC12 pheochromocytoma cells, transient RAS activation stimulates proliferation, whereas sustained RAS activation induces differentiation (Schubbert et al. 2007). Similarly, oncogenic HRAS and $C R A F$ or RAF1 alleles decreased MTC cell proliferation and increased calcitonin gene expression (Nakagawa et al. 1987, Carson-Walter et al. 1998). Such a pro-differentiating effect of constitutive RAS-RAF signalling may explain why mutations in these genes are unlikely to occur in MTC. In this context, NRAS exerted a protective effect against MTC formation as shown by the finding that NRAS deletion increased MTC formation in RB1-knock-out mice (see also below; Takahashi $e t$ al. 2006). However, the role of RAS signalling in MTC cells is probably complex and different components of the RAS family may exert different effects. In fact, when targeted to C-cells, an oncogenic HRAS mutant caused MTC in transgenic mice (Johnston et al. 1998). Similarly, Moloney murine sarcoma virus oncogene (MOS) another oncogene that potently activates ERK induced MTC and pheochromocytoma in transgenic mice (Schulz et al. 1992). With the caveat that findings obtained in artificial animal models should be interpreted with caution, it is conceivable that RAS signalling along the ERK cascade is involved in mitogenic signalling in MTC cells. In this context, it is noteworthy that inhibition of the ERK pathway reduced proliferation of a RET-mutant MTC cell line (Zatelli et al. 2005). Inhibitors of MEK are currently undergoing clinical experimentation in thyroid cancer patients (Sherman 2008).

\section{PI3K pathway}

Class I PI3K are constituted by a regulatory (p85 $\alpha$, $\mathrm{p} 55 \alpha, \mathrm{p} 50 \alpha, \mathrm{p} 85 \beta, \mathrm{p} 55 \gamma)$ and a catalytic (p110 $\alpha, \mathrm{p} 110 \beta$,

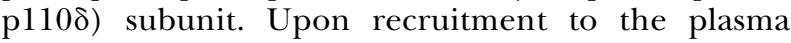
membrane by activated RTK or RAS, class I PI3K phosphorylates phosphatidylinositol-4, 5-bisphosphate to generate phosphatidylinositol-3, 4, 5-triphosphate (PIP3; Fig. 1). PIP3, in turn, activates downstream molecules such as the RAC small GTPase, 3-phosphoinositide-dependent protein kinase 1 (PDK1), and the AKT (also known as PKB) serine/ treonine kinase (Yuan \& Cantley 2008). The lipid phosphatase, phosphatase and tensin homologue deleted on chromosome 10 (PTEN) antagonizes this cascade by dephosphorylating PIP3 (Salmena et al. 2008). Besides, buffering the PI3K pathway, PTEN also 
exerts phosphatase-independent nuclear functions that may contribute to the potent oncogenic effect resulting from its inactivation in tumours (Salmena et al. 2008). AKT phosphorylates and inactivates pro-apoptotic transcription factors of the forkhead-box class $\mathrm{O}$ (FOXO) family, the cell-cycle inhibitor CDKN1B (p27Kip1), and the GSK3B kinase, thereby releasing beta-catenin from the inhibitory effects of GSK3B (see below; Fig. 1; Yuan \& Cantley 2008). In addition, AKT stimulates the serine/threonine kinase mammalian target of rapamycin (mTOR; Fig. 1). mTOR is associated with two complexes: the rapamycin-sensitive TORC1 complex (that phosphorylates S6K to regulate protein translation); and the rapamycin-insensitive TORC2 (which is the PDK2 activity that controls serine 473 phosphorylation of AKT itself; Bjornsti \& Houghton 2004). TORC1 also contributes to NF-кB activation (see below; Fig. 1).

The PI3K-AKT-mTOR cascade is important in tumourigenesis because of its ability to promote growth (cell size) and proliferation (cell number) and to prevent cell death. Mutations in major nodes of this cascade are prevalent in human cancer and include gain-of-function mutations and amplification of the genes encoding the catalytic subunit p110 $\alpha$ of PI3K (PIK3CA) and AKT (Zbuk \& Eng 2007, Yuan \& Cantley 2008). Mutations in this pathway are very frequent, for instance, in breast and colon cancer (Wood et al. 2007). Germ line inactivating mutations of PTEN cause autosomal dominant hamartoma syndromes, and somatic PTEN inactivation by deletion is very frequent (up to 30-50\%) in sporadic tumours (Zbuk \& Eng 2007, Paes \& Ringel 2008). Many studies have demonstrated that the PI3K-AKT system plays a key role in RET signalling (Segouffin-Cariou \& Billaud 2000, Kodama et al. 2005, Asai et al. 2006b). However, no systematic genetic analysis of PI3K pathway components has been reported so far in MTC. PIK3CA gene amplification, which frequently occurs in aggressive tumours of thyroid cells of follicular lineage, was not detected in 13 MTC samples (Wu et al. 2005). PTENanalysis in MTC has so far been limited to promoter methylation assessment, and no methylation was detected in a small MTC set (Schagdarsurengin et al. 2006). However, CCH and MTC occur in PTENheterozygous mice, particularly when crossed with mice knocked-out for CDKN2C (encoding the p18Ink4c cell-cycle inhibitor; see below; Bai et al. 2006). Thus, as discussed for RAS, the PI3KAKT cascade, even though infrequently mutated, may play a role in MTC. Accordingly, in vitro chemical PI3K inhibition reduced MTC cell proliferation and survival, which indicates that this pathway could be a molecular target in MTC treatment (Kunnimalaiyaan et al. 2006a). Given its central role in PI3K-AKT signalling, and the availability of potent and selective inhibitors (everolimus, temsirolimus) derived from rapamycin (sirolimus), mTOR is one of the most appealing therapeutic targets in this pathway (Bjornsti \& Houghton 2004).

\section{NF-кB}

The NF- $\kappa \mathrm{B}$ family includes five transcription factors named NF-кB1 (p50), NF-кB2 (p52), Rel, RelA (p65) and RelB. NF- $\mathrm{KB}$ activates transcription of genes associated with cell proliferation, angiogenesis, metastasis, and inflammation and suppression of apoptosis (Baud \& Karin 2009). NF-кB proteins are rendered inactive in non-stimulated cells through binding to inhibitors, known as the I $\mathrm{K} \mathrm{B}(\mathrm{I} \kappa \mathrm{B} \alpha, \beta, \varepsilon$ ) proteins. Activation of most forms of NF- $\kappa \mathrm{B}$, especially the most common form (the p50/RelA dimer), depends on phosphorylation-induced ubiquitination of I $\mathrm{B}$ that is mediated by the I $\kappa \mathrm{B}$ kinase (IKK) complex (CHUK, IKBKB, IKBKG or NEMO; Baud \& Karin 2009). Thus, $\mathrm{NF}-\kappa \mathrm{B}$ is activated by different membrane receptors as well as by BRAF that directly associates with IKK (Encinas et al. 2008) and by PI3K/AKT that mediates an mTOR/IKK interaction (Dan et al. 2008; Fig. 1). RET stimulates IKK phosphorylation and NF-KB activation, thus contributing to MTC cell survival (Ludwig et al. 2001, Encinas et al. 2008).

Recent studies have found mutations that directly target NF- $\kappa \mathrm{B}$ pathway components in human cancer (Wood et al. 2007). A genetic analysis of the NF-KB pathway in MTC has not yet been reported. Histochemical analysis of MTC tissue samples revealed that many proteins of the NF- $\kappa$ B family, particularly p65, p52 and c-Rel, are localized in the nucleus (Gallel et al. 2008). NF-кB inhibitors, particularly IKK inhibitors, are being exploited in cancer therapy (Baud \& Karin 2009). Moreover, inhibitors of the $26 \mathrm{~S}$ proteasome, such as bortezomib (Velcade), that prevent I $\kappa \mathrm{B}$ degradation and NF- $\kappa \mathrm{B}$ nuclear translocation, exerted cytotoxic effects in MTC cells (Mitsiades et al. 2006b).

\section{Beta-catenin (CTNNB1)}

Beta-catenin, which is encoded by the CTNNB1 gene, plays an important role in cellular adhesion by associating with E-cadherin and alpha-catenin. Upon disassembling of the membrane complex, beta-catenin migrates into the nucleus where it acts as a co-activator of TCF/LEF (T-cell factor/lymphoid-enhancing factor) transcriptional factors (Brembeck et al. 2006). RET stimulates beta-catenin activation via direct phosphorylation on Y654 and via PI3K/AKT- and RAS/ERKmediated inhibition of GSK3B (Fig. 1; Cassinelli et al. 2009, Gujral et al. 2008, Castellone et al. 2009). Although an analysis of the CTNNB1 gene in MTC has not yet 
been reported, MTC samples from human patients and RET(M918T) transgenic mice showed nuclear betacatenin accumulation (Gujral et al. 2008).

\section{STAT}

STAT transcription factors are activated in response to cytokines and growth factors. Cytokines activate STAT through JAK tyrosine kinases, whereas RTKs can phosphorylate STAT directly. The JAK-STAT pathway has been implicated in several neoplastic diseases, particularly myeloproliferative disorders (Levine \& Gilliland 2008). Oncogenic RET mutants induce serine phosphorylation through the RAS pathway, and tyrosine phosphorylation of STAT3 (Fig. 1; Plaza Menacho et al. 2005, 2007). Moreover, activated STAT3 was identified in the nucleus of cells from MTC samples (Plaza Menacho et al. 2005).

\section{Negative regulators of RET signalling}

Several proteins function as feedback regulators to attenuate RTK signalling and, intriguingly, the corresponding genes are often downregulated in diverse tumour types (van Staveren et al. 2006, Amit et al. 2007). Negative regulators of RET signalling have been identified. However, also in this case, no systematic analysis of genetic alterations in MTC has yet been reported. Below, we briefly discuss the effects exerted by tyrosine phosphatases (LAR, PTPRJ, SHP-1), ERK dual-specificity phosphatases (DUSP) and RAS-BRAF signalling inhibitors (SPRY) on RET signalling.

Tyrosine phosphatases dephosphorylate RET and attenuate RET signalling; theoretically, their loss could promote MTC formation (Fig. 1). Leukocyte common antigen-related (LAR) phosphatase (also called 'PTPRF', protein tyrosine phosphatase, receptor type, F) is a receptor tyrosine phosphatase that maps on a region of chromosome 1 (1p) that is frequently lost in MTC (Mathew et al. 1987, Mulligan et al. 1993). LAR forms stable complexes with RET and dephosphorylates RET cysteine mutants (but not RET-M918T) thereby blunting cell proliferation (Qiao et al. 2001). Similarly, the receptor-protein tyrosine phosphatase J (PTPRJ) binds and de-phosphorylates RET cysteine mutants and thus impairs their transforming effect (Iervolino et al. 2006). The SHP-1, SHP-2 are nontransmembrane phosphotyrosine phosphatases (PTPN6 and PTPN11 respectively). While SHP-2 functions as a positive RTK signal transducer and stimulates downstream RET signalling along the RAS cascade (D'Alessio et al. 2003), SHP-1 serves as a negative regulator of signalling systems. SHP-1 associates with RET, restrains RET autophosphorylation, and inhibits MTC cell proliferation (Hennige et al. 2001,
Incoronato et al. 2004, Zatelli et al. 2005). Intriguingly, SHP-1 is involved in the cytostatic effects of somatostatin in MTC cells (Zatelli et al. 2005).

Activated ERKs are inactivated through dephosphorylation of threonine and/or tyrosine residues within the activation loop. The DUSP, also called 'MAP kinase phosphatases' (MKP), carries out this function (Fig. 1; Kondoh \& Nishida 2007). Intriguingly, MKPs/DUSPs are rapidly induced upon growth factor signalling, and functions as feedback regulators of the pathway (Amit et al. 2007). RET-mediated signalling increased MKP-3 levels (Colucci-D'Amato et al. 2000). In principle, a lossof-function of MKPs may favour RET signalling along the ERK cascade. However, it should be noted that the pro-mitogenic and anti-mitogenic effects of MKPs/DUSPs may vary depending on the specific complement of MAPK family members they dephosphorylate. For instance, DUSP4/MKP-2, which dephosphorylates not only p42/44 MAPK (ERK) but also p38MAPK and JNK, exerts a positive (rather than a negative) role in RETmediated tumourigenesis and it is upregulated in MTC samples (Hasegawa et al. 2008).

Sprouty (SPRY) and Spred proteins are evolutionarily conserved inhibitors of signalling that act by blocking RAS-RAF interaction and ERK activation. The expression of SPRY family members is induced by RET, and SPRY2 blunted RET-ERK signalling (Ishida et al. 2007). Intriguingly, genetic ablation of SPRY2 led to enteric neuronal hyperplasia by promoting RET signalling (Taketomi et al. 2005). Similarly, SPRY1deficient mice had kidney defects because of RET hypersignalling (Basson et al. 2005). SPRY/SPRED downregulation has been reported in several human cancers (Lo et al. 2006). Germ line loss-of-function mutations in SPRED1 caused a neurofibromatosis 1-like syndrome (Brems et al. 2007). Thus, a loss of SPRY/ $S P R E D$ family members in C-cells can, in principle, favour MTC formation.

\section{Other growth factor receptors}

It is conceivable that other RTKs, besides RET, are involved in MTC. This point is of great topical interest because tyrosine kinase inhibitors are now being tested in MTC patients (Castellone et al. 2008, Sherman 2008). Proliferation of cultured MTC cells is stimulated by insulin-like growth factor 1 (IGF1) and inhibited by compounds targeting IGF1-R (Yang et al. 1992, Mitsiades et al. 2004). NTRKs, which are tyrosine kinase receptors for growth factors of the nerve growth factor family, have been studied in MTC because, like RET, they exert neurotrophic effects and are involved in PTC (NTRK1 rearrangements; Pierotti \& Greco 2006). Moreover, there is functional evidence that NTRK1-RET signalling is involved in neuronal cell survival (Tsui-Pierchala et al. 2002, Luo et al. 2007, Pierchala et al. 2007). Although no 
mutations have been found in NTRK1, 2 and 3 (Gimm et al. 1999, 2001b), NTRK2 expression was reduced, whereas NTRK3 expression was increased in MTC (McGregor et al. 1999). Moreover, NTRK2 expression impaired the tumourigenicity of MTC cells (McGregor et al. 1999). Interaction between epidermal growth factor receptor (EGFR) and RET was recently found to mediate EGFR-dependent RET activation (Croyle $e t$ al. 2008). Phosphorylated EGFR has been identified in MTC cells (Gorla et al. 2008). It is noteworthy that Vandetanib, a RET kinase inhibitor currently being investigated in MTC patients, is also an EGFR inhibitor (Carlomagno et al. 2002). No mutation in EGFR was found in small MTC sample sets (Mitsiades et al. 2006a, Cerrato \& Santoro unpublished). Fibroblast growth factor receptor-4 (FGFR4) is expressed in aggressive thyroid tumour types and MTC cells. Molecular targeting of FGFR-4 with an ATP-competitive inhibitor prevented the growth and reduced the tumourigenesis of MTC cells (Ezzat et al. 2005).

Finally, membrane receptors of families other than the RTK family have been implicated in MTC. NOTCH1 is a multifunctional transmembrane receptor that regulates cell differentiation, development, proliferation and survival. Binding of several ligands promotes proteolytic cleavage events, which result in the release of the NOTCH1 intracellular domain that, in turn, translocates to the nucleus and activates transcription of various target genes. NOTCH1 is a negative regulator of ASH1 (achaete-scute homolog-1, called 'MASH1' in rodents), which is a highly conserved basic helix-loop-helix transcription factor that is critical for C-cell development (Lanigan et al. 1998). Interestingly, MTC expresses ASH1 but not NOTCH1, and NOTCH1 expression arrested proliferation of MTC cells (Kunnimalaiyaan et al. 2006b). The prolactin receptor (PRLR) belongs to the cytokine receptor family and activates the JAK-STAT pathway. Unexpectedly, PRLR-null mice developed MTC at a high frequency, thereby suggesting that PRLR suppresses MTC formation at least in mice (Kedzia et al. 2005).

\section{Tumour suppressors of the RB1 and TP53 pathways in MTC}

The tumour-suppressor genes $R B 1$ (retinoblastoma: pRB protein) and TP53 (p53 protein) are frequently mutated in human cancer, and several lines of evidence indicate that both pathways must be inactivated in cancer to overcome senescence or apoptosis (Hahn \& Weinberg 2002). RB1 is the prototypic member of the class of tumour suppressors known as 'gatekeepers', which control tumour growth in a cell-autonomous manner. This mainly depends on pRB's ability to repress the effect exerted by the E2F/DP family of transcription factors, namely, stimulation of cell-cycle progression or apoptosis (Fig. 2; Hahn \& Weinberg 2002). Binding of the $\mathrm{pRB}$ protein to $\mathrm{E} 2 \mathrm{~F} / \mathrm{DP}$ transcription factors is high when $\mathrm{pRB}$ is hypophosphorylated in G1, and low when pRB is hyperphosphorylated in S and G2 phases. pRB is phosphorylated sequentially by D-, E- and A-type cyclin-mediated CDK activity. In turn, CDKs are negatively regulated by CDK inhibitors (CKI) of the INK4 (p16INK4A, p15INK4B, p18INK4C, p19INK4D) and CIP/KIP (p21CIP1, p27KIP1, p57KIP2) families (Fig. 2). Tethering of pRB to E2F target genes results in cell-cycle arrest (Trimarchi \& Lees 2002). There are multiple interactions between the pRB and the p53 pathways (Fig. 2). On one hand, by stimulating transcription of the p21CIP1 (CDKN1A) cell-cycle inhibitor, p53 obstructs the activity of cyclin E/CDK complexes, thereby reducing $\mathrm{pRB}$ phosphorylation and, consequently, E2F activity. On the other hand, lossof-function of $\mathrm{pRB}$ releases not only the pro-mitogenic but also pro-apoptotic activity of E2F transcription factors. The final outcome may depend on TP53 genetic status because E2F-mediated apoptosis is dependent on the upregulation of p14ARF (CDKN2B) that in turn stabilizes p53. Therefore, in cancer, $R B 1$ and TP53 are often concurrently mutated (Hahn \& Weinberg 2002).

There is extensive genetic evidence in rodents that the pRB and p53 pathways are involved in MTC. RB1deficient mice developed MTC (Harrison et al. 1995). Conditional $R B 1$ inactivation also induced highly aggressive MTC in mice (Kucherlapati et al. 2006). Loss of TP53 further increased MTC formation in RB1deficient mice (Williams et al. 1994, Harvey et al. 1995). E2F family transcription factors exerted a dual role in MTC formation. Genetic deletion of E2F1 or E2F4 reduced MTC formation in RB1-deficient mice (Yamasaki et al. 1998, Lee et al. 2002). Instead, deletion of $E 2 F 3$ further increased the incidence and aggressiveness of MTC (Ziebold et al. 2003).

Interestingly, MTC from $R B 1 / T P 53$-deficient mice acquired somatic cysteine mutations in RET that closely resemble activating mutations observed in human MTC. This suggested that murine MTC requires mutational dysregulation within both the RET and nuclear tumour suppressor gene pathways (Coxon et al. 1998). High grade MTC were observed in mice simultaneously lacking $R B 1$ and $C D K N 1 B$ (that codes for the p27Kip1 cell-cycle inhibitor; Park et al. 1999). Interestingly, germ line mutation in $C D K N 1 B$ predisposed rats to a multiple endocrine neoplasia syndrome featuring MTC formation (Pellegata et al. 2006). In transgenic mice, the loss of two CDKIs, CDKN1B and CDKN2C (coding for the p18INK4C cell-cycle inhibitor), led to accelerated MTC formation (Franklin et al. 2000, Joshi et al. 2007). CDKN2C deficiency also accelerated MTC formation in PTEN-deficient mice (Bai et al. 2006). Finally, transgenic mice expressing 
oncogenic RET crossed with mice lacking CDKN2C developed MTC at a higher incidence and sooner than their single mutant littermates (van Veelen et al. 2008).

Taken together, these studies provide robust evidence that, in rodents, disruption of the $R B 1$ and TP53 pathways predisposes to MTC formation. However, mice models may not faithfully mimic the human situation, and the tumour spectrum may significantly differ in the two species. A prominent example of this concept is provided by the phenotype of $R B 1$-deficient mice. In humans, loss of the $R B 1$ gene is associated with the development of retinoblastoma and osteosarcoma and, later in life, small-cell lung carcinoma, whereas RB1-deleted mice do not develop these types of tumours, and develop retinoblastoma only when the RB1-related RBL1 gene is concurrently deleted (Rangarajan \& Weinberg 2003). Previous studies did not find TP53-mutations in sets of 9 (Yoshimoto et al. 1992) and 22 (Herfarth et al. 1997) MTC samples. More recent studies identified a high prevalence of TP53 mutations (Pavelić et al. 2006) and deletions in MTC (Sheikh et al. 2004). Very recently, about $10 \%$ of MTCs were found to carry loss-of-function mutations in CDKN2C (van Veelen et al. 2009); however, we did not find any CDKN2C-mutation in 15 MTC samples (Cerrato \& Santoro unpublished). A systematic analysis of the genes in the RB1 and TP53 pathways in human samples will help to clarify their role in MTC formation. Given the role played by these tumour-suppressor pathways in the response of tumours to therapy, this information might be important for the analysis of data from the ongoing MTC trials involving the use of targeted agents.

\section{Conclusions}

The identification of RET mutations has revolutionized the medical treatment of patients with FMTC. Twentyfive years after this seminal discovery, no other genetic lesion has been consistently associated with MTC formation. Studies of the RET pathway and mouse models of MTC formation are generating an evergrowing list of genes, including the recently described CDKN2C gene (p18INK4C cell-cycle inhibitor), that could play a role in MTC. Biochemical data also indicate that these pathways play a role in MTC formation. A thorough analysis of these genes has not yet been performed, and the results of the few studies available, conducted, moreover, on a limited number of samples, are often conflicting. An unbiased genomewide analysis of sequence variations, copy gains and losses will probably provide groundbreaking information as has occurred for various tumour types (Sjöblom 2008). It is expected that identification of lesions in genes other than RET will clarify the biology of MTC and foster the development of targeted therapeutic approaches. In any event, the data acquired in recent years about the signalling mechanisms operating in MTC show that molecular targeting of pathways like the RAS/ERK, PI3K/AKT and NF-KB pathways is a plausible therapeutic approach for this cancer.

\section{Declaration of interest}

There is no conflict of interest that could be perceived as prejudicing the impartiality of the research reported.

\section{Funding}

This work was supported by the Associazione Italiana per la Ricerca sul Cancro (AIRC, 2008-2010), the Italian Ministero della Salute (2008-2009), and Ministero dell'Universita' e della Ricerca (MiUR) (2008-2009).

\section{Acknowledgements}

We gratefully acknowledge members of our laboratory for their continuous support. We are grateful to Jean Ann Gilder for text editing and StudioCiotola for art-work.

\section{References}

Acton DS, Velthuyzen D, Lips CJ \& Höppener JW 2000 Multiple endocrine neoplasia type 2B mutation in human RET oncogene induces medullary thyroid carcinoma in transgenic mice. Oncogene 19 3121-3125.

Airaksinen MS \& Saarma M 2002 The GDNF family: signalling, biological functions and therapeutic value. Nature Reviews. Neuroscience 3 383-394.

Amit I, Citri A, Shay T, Lu Y, Katz M, Zhang F, Tarcic G, Siwak D, Lahad J, Jacob-Hirsch J et al. 2007 A module of negative feedback regulators defines growth factor signaling. Nature Genetics 39 503-512.

Asai N, Fukuda T, Wu Z, Enomoto A, Pachnis V, Takahashi M \& Costantini F 2006 $a$ Targeted mutation of serine 697 in the Ret tyrosine kinase causes migration defect of enteric neural crest cells. Development 133 4507-4516.

Asai N, Jijiwa M, Enomoto A, Kawai K, Maeda K, Ichiahara M, Murakumo Y \& Takahashi M 2006b RET receptor signaling: dysfunction in thyroid cancer and Hirschsprung's disease. Pathology International 56 164-172.

Bai F, Pei XH, Pandolfi PP \& Xiong Y 2006 p18 Ink4c and Pten constrain a positive regulatory loop between cell growth and cell cycle control. Molecular and Cellular Biology 26 4564-4576.

Basson MA, Akbulut S, Watson-Johnson J, Simon R, Carroll TJ, Shakya R, Gross I, Martin GR, Lufkin T, McMahon AP et al. 2005 Sproutyl is a critical regulator of GDNF/RET-mediated kidney induction. Developmental Cell 8 229-239.

Baud V \& Karin M 2009 Is NF- $\mathrm{B}$ a good target for cancer therapy? Hopes and pitfalls Nature Reviews. Drug Discovery $833-40$.

Bjornsti MA \& Houghton PJ 2004 The TOR pathway: a target for cancer therapy. Nature Reviews. Cancer 4 335-348.

Bockhorn M, Frilling A, Kalinin V, Schröder S \& Broelsch CE 2000 Absence of $\mathrm{H}$ - and K-ras oncogene mutations in sporadic medullary thyroid carcinoma. Experimental and Clinical Endocrinology and Diabetes 108 49-53. 
Borrego S, Eng C, Sánchez B, Sáez ME, Navarro E \& Antiñolo G 1998 Molecular analysis of the ret and GDNF genes in a family with multiple endocrine neoplasia type 2A and Hirschsprung disease. Journal of Clinical Endocrinology and Metabolism 83 3361-3364.

Borrello MG, Alberti L, Arighi E, Bongarzone I, Battistini C, Bardelli A, Pasini B, Piutti C, Rizzetti MG, Mondellini P et al. 1996 The full oncogenic activity of Ret/ptc2 depends on tyrosine 539, a docking site for phospholipase Cgamma. Molecular and Cellular Biology 16 2151-2163.

Brandi ML, Gagel RF, Angeli A, Bilezikian JP, Beck-Peccoz P, Bordi C, Conte-Devolx B, Falchetti A, Gheri RG, Libroia A et al. 2001 Guidelines for diagnosis and therapy of MEN type 1 and type 2. Journal of Clinical Endocrinology and Metabolism 86 5658-5671.

Brembeck FH, Rosário M \& Birchmeier W 2006 Balancing cell adhesion and Wnt signaling, the key role of beta-catenin. Current Opinion in Genetics and Development 16 51-59.

Brems H, Chmara M, Sahbatou M, Denayer E, Taniguchi K, Kato R, Somers R, Messiaen L, De Schepper S, Fryns JP et al. 2007 Germline loss-of-function mutations in SPRED1 cause a neurofibromatosis 1-like phenotype. Nature Genetics 39 1120-1126.

Carlomagno F, Vitagliano D, Guida T, Ciardiello F, Tortora G, Vecchio G, Ryan AJ, Fontanini G, Fusco A \& Santoro M 2002 ZD6474, an orally available inhibitor of KDR tyrosine kinase activity, efficiently blocks oncogenic RET kinases. Cancer Research 15 7284-7290.

Carson-Walter EB, Smith DP, Ponder BA, Baylin SB \& Nelkin BD 1998 Post-transcriptional silencing of RET occurs, but is not required, during raf-1 mediated differentiation of medullary thyroid carcinoma cells. Oncogene 17 367-376.

Cascon A, Cebrian A, Pollan M, Ruiz-Llorente S, Montero-Conde C, Leton R, Gutierrez R, Lesueur F, Milne RL, Gonzalez-Albarran O et al. 2005 Succinate dehydrogenase $\mathrm{D}$ variants do not constitute a risk factor for developing $\mathrm{C}$ cell hyperplasia or sporadic medullary thyroid carcinoma. Journal of Clinical Endocrinology and Metabolism 90 2127-2130.

Cassinelli G, Favini E, Degl'Innocenti D, Salvi A, De Petro G, Pierotti MA, Zunino F, Borrello MG \& Lanzi C 2009 RET/PTC1driven neoplastic transformation and proinvasive phenotype of human thyrocytes involve Met induction and beta-catenin nuclear translocation. Neoplasia 11 10-21.

Castellone MD, Carlomagno F, Salvatore G \& Santoro M 2008 Receptor tyrosine kinase inhibitors in thyroid cancer. Best Practice and Research. Clinical Endocrinology and Metabolism 22 1023-1038.

Castellone MD, De Falco V, Rao DM, Bellelli R, Muthu M, Basolo F, Fusco A, Gutkind JS \& Santoro M 2009 The $\beta$-catenin axis integrates multiple signals downstream from RET/PTC and leads to cell proliferation. Cancer Research 69 1867-1876.

Cebrian A, Lesueur F, Martin S, Leyland J, Ahmed S, Luccarini C, Smith PL, Luben R, Whittaker J, Pharoah PD et al. 2005 Polymorphisms in the initiators of RET (rearranged during transfection) signaling pathway and susceptibility to sporadic medullary thyroid carcinoma. Journal of Clinical Endocrinology and Metabolism 90 6268-6274.

Chiariello M, Visconti R, Carlomagno F, Melillo RM, Bucci C, de Franciscis V, Fox GM, Jing S, Coso OA, Gutkind JS et al. 1998 Signalling of the Ret receptor tyrosine kinase through the c-Jun NH2-terminal protein kinases (JNKS): evidence for a divergence of the ERKs and JNKs pathways induced by Ret. Oncogene 16 2435-2445.

Colucci-D'Amato GL, D'Alessio A, Califano D, Cali G, Rizzo C, Nitsch L, Santelli G \& de Franciscis V 2000 Abrogation of nerve growth factorinduced terminal differentiation by ret oncogene involves perturbation of nuclear translocation of ERK. Journal of Biological Chemistry 275 19306-19314.

Coxon AB, Ward JM, Geradts J, Otterson GA, Zajac-Kaye M \& Kaye FJ 1998 RET cooperates with RB/p53 inactivation in a somatic multi-step model for murine thyroid cancer. Oncogene 17 $1625-1628$.
Cranston AN \& Ponder BA 2003 Modulation of medullary thyroid carcinoma penetrance suggests the presence of modifier genes in a RET transgenic mouse model. Cancer Research 63 4777-4780.

Croyle M, Akeno N, Knauf JA, Fabbro D, Chen X, Baumgartner JE, Lane H \& Fagin JA 2008 RET/PTC-induced cell growth is mediated in part by epidermal growth factor receptor (EGFR) activation: evidence for molecular and functional interactions between RET and EGFR. Cancer Research 68 4183-4191.

D'Alessio A, Califano D, Incoronato M, Santelli G, Florio T, Schettini G, Carlomagno MS, Cerchia L \& de Franciscis V 2003 The tyrosine phosphatase Shp-2 mediates intracellular signaling initiated by Ret mutants. Endocrinology 144 4298-4305.

Dan HC, Cooper MJ, Cogswell PC, Duncan JA, Ting JP \& Baldwin AS 2008 Akt-dependent regulation of NF- $\kappa \mathrm{B}$ is controlled by mTOR and Raptor in association with IKK. Genes and Development 22 $1490-1500$

Drosten M, Hilken G, Böckmann M, Rödicker F, Mise N, Cranston AN, Dahmen U, Ponder BA \& Pützer BM 2004 Role of MEN2A-derived RET in maintenance and proliferation of medullary thyroid carcinoma. Journal of the National Cancer Institute 96 1231-1239.

Elisei R, Cosci B, Romei C, Bottici V, Sculli M, Lari R, Barale R, Pacini F \& Pinchera A 2004 RET exon 11 (G691S) polymorphism is significantly more frequent in sporadic medullary thyroid carcinoma than in the general population. Journal of Clinical Endocrinology and Metabolism 89 3579-3584.

Elisei R, Romei C, Cosci B, Agate L, Bottici V, Molinaro E, Sculli M, Miccoli P, Basolo F, Grasso L et al. 2007 RET genetic screening in patients with medullary thyroid cancer and their relatives: experience with 807 individuals at one center. Journal of Clinical Endocrinology and Metabolism 92 4725-4729.

Elisei R, Cosci B, Romei C, Bottici V, Renzini G, Molinaro E, Agate L, Vivaldi A, Faviana P, Basolo F et al. 2008 Prognostic significance of somatic RET oncogene mutations in sporadic medullary thyroid cancer: a 10-year follow-up study. Journal of Clinical Endocrinology and Metabolism 93 682-687.

Encinas M, Crowder RJ, Milbrandt J \& Johnson EM Jr 2004 Tyrosine 981, a novel ret autophosphorylation site, binds c-Src to mediate neuronal survival. Journal of Biological Chemistry 279 18262-18269.

Encinas M, Rozen EJ, Dolcet X, Jain S, Comella JX, Milbrandt J \& Johnson EM Jr 2008 Analysis of Ret knockin mice reveals a critical role for IKKs, but not PI 3-K, in neurotrophic factor-induced survival of sympathetic neurons. Cell Death and Differentiation 15 $1510-1521$.

Ezzat S, Huang P, Dackiw A \& Asa SL 2005 Dual inhibition of RET and FGFR4 restrains medullary thyroid cancer cell growth. Clinical Cancer Research 11 1336-1341.

Fagin JA 2005 Genetics of papillary thyroid cancer initiation: implications for therapy. Transactions of the American Clinical and Climatological Association 116 259-269.

Ferris RL \& Simental AA Jr 2004 Molecular biology of primary hyperparathyroidism. Otolaryngologic Clinics of North America $\mathbf{3 7}$ 819-831.

Franklin DS, Godfrey VL, O'Brien DA, Deng C \& Xiong Y 2000 Functional collaboration between different cyclin-dependent kinase inhibitors suppresses tumor growth with distinct tissue specificity. Molecular and Cellular Biology 20 6147-6158.

Fukuda T, Kiuchi K \& Takahashi M 2002 Novel mechanism of regulation of Rac activity and lamellipodia formation by RET tyrosine kinase. Journal of Biological Chemistry 277 19114-19121.

Gagel FR \& Marx SJ 2003 Multiple endocrine neoplasia. In Williams Textbook of Endocrinology, 10 edn, pp 1717-1762. Eds PR Larsen, H Kronenberg, S Melmed \& K Polonsky. Philadelphia: Saunders, Elsevier Science.

Gallel P, Pallares J, Dolcet X, Llobet D, Eritja N, Santacana M, Yeramian A, Palomar-Asenjo V, Lagarda H, Mauricio D et al. 2008 Nuclear factor-kappaB activation is associated with somatic and germ line RET mutations in medullary thyroid carcinoma. Human Pathology 39 994-1001. 
Gimm O, Greco A, Hoang-Vu C, Dralle H, Pierotti MA \& Eng C 1999 Mutation analysis reveals novel sequence variants in NTRK1 in sporadic human medullary thyroid carcinoma. Journal of Clinical Endocrinology and Metabolism 84 2784-2787.

Gimm O, Dziema H, Brown J, Hoang-Vu C, Hinze R, Dralle H, Mulligan LM \& Eng C 2001 $a$ Over-representation of a germline variant in the gene encoding RET co-receptor GFRalpha-1 but not GFRalpha-2 or GFRalpha-3 in cases with sporadic medullary thyroid carcinoma. Oncogene 20 2161-2170.

Gimm O, Dziema H, Brown J, de la Puente A, Hoang-Vu C, Dralle H, Plass C \& Eng C $2001 b$ Mutation analysis of NTRK2 and NTRK3, encoding 2 tyrosine kinase receptors, in sporadic human medullary thyroid carcinoma reveals novel sequence variants. International Journal of Cancer 92 70-74.

Gorla L, Mondellini P, Cuccuru G, Miccichè F, Cassinelli G, Cremona M, Pierotti MA, Lanzi C \& Bongarzone I 2009 Proteomics study of medullary thyroid carcinomas expressing RET germ-line mutations: identification of new signaling elements. Molecular Carcinogenesis 48 220-231.

Goutas N, Vlachodimitropoulos D, Bouka M, Lazaris AC, Nasioulas G \& Gazouli M 2008 BRAF and K-RAS mutation in a Greek papillary and medullary thyroid carcinoma cohort. Anticancer Research 28 305-308.

Gujral TS, van Veelen W, Richardson DS, Myers SM, Meens JA, Acton DS, Duñach M, Elliott BE, Höppener JW \& Mulligan LM 2008 A novel RET kinase-beta-catenin signaling pathway contributes to tumorigenesis in thyroid carcinoma. Cancer Research 68 1338-1346.

Hahn WC \& Weinberg RA 2002 Modelling the molecular circuitry of cancer. Nature Reviews. Cancer 2 331-341.

Halilovic E \& Solit DB 2008 Therapeutic strategies for inhibiting oncogenic BRAF signaling. Current Opinion in Pharmacology 8 $419-426$.

Harrison DJ, Hooper ML, Armstrong JF \& Clarke AR 1995 Effects of heterozygosity for the Rb-1t19neo allele in the mouse. Oncogene $\mathbf{1 0}$ $1615-1620$.

Harvey M, Vogel H, Lee EY, Bradley A \& Donehower LA 1995 Mice deficient in both p53 and $\mathrm{Rb}$ develop tumors primarily of endocrine origin. Cancer Research 55 1146-1151.

Hasegawa T, Enomoto A, Kato T, Kawai K, Miyamoto R, Jijiwa M, Ichihara M, Ishida M, Asai N, Murakumo Y et al. 2008 Roles of induced expression of MAPK phosphatase-2 in tumor development in RET-MEN2A transgenic mice. Oncogene 27 5684-5695.

Hennige AM, Lammers R, Höppner W, Arlt D, Strack V, Teichmann R, Machicao F, Ullrich A, Häring HU \& Kellerer M 2001 Inhibition of Ret oncogene activity by the protein tyrosine phosphatase SHP1. Endocrinology 142 4441-4447.

Herfarth KK, Wick MR, Marshall HN, Gartner E, Lum S \& Moley JF 1997 Absence of TP53 alterations in pheochromocytomas and medullary thyroid carcinomas. Genes, Chromosomes and Cancer $\mathbf{2 0}$ 24-29.

Horie H, Yokogoshi Y, Tsuyuguchi M \& Saito S 1995 Point mutations of ras and Gs alpha subunit genes in thyroid tumors. Japanese Journal of Cancer Research 86 737-742.

Huang SC, Torres-Cruz J, Pack SD, Koch CA, Vortmeyer AO, Mannan P, Lubensky IA, Gagel RF \& Zhuang Z 2003 Amplification and overexpression of mutant RET in multiple endocrine neoplasia type 2-associated medullary thyroid carcinoma. Journal of Clinical Endocrinology and Metabolism 88 459-463.

Iavarone C, Acunzo M, Carlomagno F, Catania A, Melillo RM, Carlomagno SM, Santoro M \& Chiariello M 2006 Activation of the Erk8 mitogen-activated protein (MAP) kinase by RET/PTC3, a constitutively active form of the RET proto-oncogene. Journal of Biological Chemistry 281 10567-10576.

Iervolino A, Iuliano R, Trapasso F, Viglietto G, Melillo RM, Carlomagno F, Santoro M \& Fusco A 2006 The receptor-type protein tyrosine phosphatase $\mathrm{J}$ antagonizes the biochemical and biological effects of RET-derived oncoproteins. Cancer Research 66 6280-6287.
Incoronato M, D'Alessio A, Paladino S, Zurzolo C, Carlomagno MS, Cerchia L \& de Franciscis V 2004 The Shp-1 and Shp-2, tyrosine phosphatases, are recruited on cell membrane in two distinct molecular complexes including Ret oncogenes. Cellular Signalling $16847-856$.

Ishida M, Ichihara M, Mii S, Jijiwa M, Asai N, Enomoto A, Kato T, Majima A, Ping J, Murakumo Y et al. 2007 Sprouty2 regulates growth and differentiation of human neuroblastoma cells through RET tyrosine kinase. Cancer Research 98 815-821.

Jain S, Encinas M, Johnson EM Jr \& Milbrandt J 2006 Critical and distinct roles for key RET tyrosine docking sites in renal development. Genes and Development 20 321-333.

Johnston D, Hatzis D \& Sunday ME 1998 Expression of v-Ha-ras driven by the calcitonin/calcitonin gene-related peptide promoter: a novel transgenic murine model for medullary thyroid carcinoma. Oncogene 16 167-177.

Joshi PP, Kulkarni MV, Yu BK, Smith KR, Norton DL, Veelen W, Höppener JW \& Franklin DS 2007 Simultaneous downregulation of CDK inhibitors p18(Ink4c) and p27(Kip1) is required for MEN2ARET-mediated mitogenesis. Oncogene 26 554-570.

Kaelin WG Jr 2008 The von Hippel-Lindau tumour suppressor protein: $\mathrm{O}_{2}$ sensing and cancer. Nature Reviews. Cancer 8 865-873.

Kawai K, Iwashita T, Murakami H, Hiraiwa N, Yoshiki A, Kusakabe M, Ono K, Iida K, Nakayama A \& Takahashi M 2000 Tissue-specific carcinogenesis in transgenic mice expressing the RET protooncogene with a multiple endocrine neoplasia type 2A mutation. Cancer Research 60 5254-5260.

Kedzia C, Lacroix L, Ameur N, Ragot T, Kelly PA, Caillou B \& Binart N 2005 Medullary thyroid carcinoma arises in the absence of prolactin signaling. Cancer Research 65 8497-8503.

Khosla S, Patel VM, Hay ID, Schaid DJ, Grant CS, van Heerden JA \& Thibodeau SN 1991 Loss of heterozygosity suggests multiple genetic alterations in pheochromocytomas and medullary thyroid carcinomas. Journal of Clinical Investigation 87 1691-1699.

Knowles PP, Murray-Rust J, Kjaer S, Scott RP, Hanrahan S, Santoro M, Ibáñez CF \& McDonald NQ 2006 Structure and chemical inhibition of the RET tyrosine kinase domain. Journal of Biological Chemistry 281 33577-33587.

Koch CA, Brouwers FM, Vortmeyer AO, Tannapfel A, Libutti SK, Zhuang Z, Pacak K, Neumann HP \& Paschke R 2006 Somatic VHL gene alterations in MEN2-associated medullary thyroid carcinoma. BMC Cancer 6131.

Kodama Y, Asai N, Kawai K, Jijiwa M, Murakumo Y, Ichihara M \& Takahashi M 2005 The RET proto-oncogene: a molecular therapeutic target in thyroid cancer. Cancer Research 96 143-148.

Kondo T, Ezzat S \& Asa SL 2006 Pathogenetic mechanisms in thyroid follicular-cell neoplasia. Nature Reviews. Cancer 6 292-306.

Kondoh K \& Nishida E 2007 Regulation of MAP kinases by MAP kinase phosphatases. Biochimica et Biophysica Acta 1773 1227-1237.

Kouvaraki MA, Shapiro SE, Perrier ND, Cote GJ, Gagel RF, Hoff AO, Sherman SI, Lee JE \& Evans DB 2005 RET proto-oncogene: a review and update of genotype-phenotype correlations in hereditary medullary thyroid cancer and associated endocrine tumors. Thyroid 15 531-544.

Kucherlapati MH, Nguyen AA, Bronson RT \& Kucherlapati RS 2006 Inactivation of conditional $\mathrm{Rb}$ by Villin-Cre leads to aggressive tumors outside the gastrointestinal tract. Cancer Research $\mathbf{6 6}$ 3576-3583.

Kunnimalaiyaan M, Ndiaye M \& Chen H $2006 a$ Apoptosis-mediated medullary thyroid cancer growth suppression by the PI3K inhibitor LY294002. Surgery 140 1009-1014.

Kunnimalaiyaan M, Vaccaro AM, Ndiaye MA \& Chen H $2006 b$ Overexpression of the NOTCH1 intracellular domain inhibits cell proliferation and alters the neuroendocrine phenotype of medullary thyroid cancer cells. Journal of Biological Chemistry 281 39819-39830. 
Lanigan TM, DeRaad SK \& Russo AF 1998 Requirement of the MASH1 transcription factor for neuroendocrine differentiation of thyroid C cells. Journal of Neurobiology 34 126-134.

Lee EY, Cam H, Ziebold U, Rayman JB, Lees JA \& Dynlacht BD 2002 E2F4 loss suppresses tumorigenesis in Rb mutant mice. Cancer Cell 2 463-472.

Lesueur F, Cebrian A, Robledo M, Niccoli-Sire P, Svensson KA, Pinson S, Leyland J, Whittaker J, Pharoah PD \& Ponder BA 2006 Polymorphisms in RET and its coreceptors and ligands as genetic modifiers of multiple endocrine neoplasia type 2A. Cancer Research 66 1177-1180.

Levine RL \& Gilliland DG 2008 Myeloproliferative disorders. Blood 112 2190-2198.

Lima J, Teixeira-Gomes J, Soares P, Máximo V, Honavar M, Williams D \& Sobrinho-Simões M 2003 Germline succinate dehydrogenase subunit D mutation segregating with familial non-RET C cell hyperplasia. Journal of Clinical Endocrinology and Metabolism 88 4932-4937.

Lindahl M, Poteryaev D, Yu L, Arumae U, Timmusk T, Bongarzone I, Aiello A, Pierotti MA, Airaksinen MS \& Saarma M 2001 Human glial cell line-derived neurotrophic factor receptor alpha 4 is the receptor for persephin and is predominantly expressed in normal and malignant thyroid medullary cells. Journal of Biological Chemistry 276 9344-9351.

Lindfors PH, Lindahl M, Rossi J, Saarma M \& Airaksinen MS 2006 Ablation of persephin receptor glial cell line-derived neurotrophic factor family receptor alpha4 impairs thyroid calcitonin production in young mice. Endocrinology 147 2237-2244.

Lo TL, Fong CW, Yusoff P, McKie AB, Chua MS, Leung HY \& Guy GR 2006 Sprouty and cancer: the first terms report. Cancer Letters $\mathbf{2 4 2}$ 141-150.

Ludwig L, Kessler H, Wagner M, Hoang-Vu C, Dralle H, Adler G, Böhm BO \& Schmid RM 2001 Nuclear factor-kappaB is constitutively active in C-cell carcinoma and required for RET-induced transformation. Cancer Research 61 4526-4535.

Luo W, Wickramasinghe SR, Savitt JM, Griffin JW, Dawson TM \& Ginty DD 2007 A hierarchical NGF signaling cascade controls Ret-dependent and Ret-independent events during development of nonpeptidergic DRG neurons. Neuron 54 739-754.

Machens A \& Dralle H 2007 Genotype-phenotype based surgical concept of hereditary medullary thyroid carcinoma. World Journal of Surgery 31 957-968.

Maher ER \& Eng C 2002 The pressure rises: update on the genetics of phaeochromocytoma. Human Molecular Genetics 11 2347-2354.

Marsh DJ, Zheng Z, Arnold A, Andrew SD, Learoyd D, Frilling A, Komminoth P, Neumann HP, Ponder BA, Rollins BJ et al. 1997 Mutation analysis of glial cell line-derived neurotrophic factor, a ligand for an RET/coreceptor complex, in multiple endocrine neoplasia type 2 and sporadic neuroendocrine tumors. Journal of Clinical Endocrinology and Metabolism 82 3025-3028.

Marsh DJ, Theodosopoulos G, Martin-Schulte K, Richardson AL, Philips J, Röher HD, Delbridge L \& Robinson BG 2003 Genomewide copy number imbalances identified in familial and sporadic medullary thyroid carcinoma. Journal of Clinical Endocrinology and Metabolism 88 1866-1872.

Marx SJ 2005 Molecular genetics of multiple endocrine neoplasia types 1 and 2. Nature Reviews. Cancer 5 367-375.

Mathew CG, Smith BA, Thorpe K, Wong Z, Royle NJ, Jeffreys AJ \& Ponder BA 1987 Deletion of genes on chromosome 1 in endocrine neoplasia. Nature 328 524-526.

Matias-Guiu X, Bussolati G, DeLellis R, Kaserer K, Moley JF, Williams ED, Gagel RF, Baloch Z \& Arbores-Saavedra J 2004 Medullary thyroid carcinoma. In World Health Organization Classification of Tumours. Pathology and Genetics. Tumours of Endocrine Organs, pp 86-91. Ed RA DeLellis et al.. Geneva: WHO Press.
McGregor LM, McCune BK, Graff JR, McDowell PR, Romans KE, Yancopoulos GD, Ball DW, Baylin SB \& Nelkin BD 1999 Roles of trk family neurotrophin receptors in medullary thyroid carcinoma development and progression. PNAS 96 4540-4545.

Michiels FM, Chappuis S, Caillou B, Pasini A, Talbot M, Monier R, Lenoir GM, Feunteun J \& Billaud M 1997 Development of medullary thyroid carcinoma in transgenic mice expressing the RET protooncogene altered by a multiple endocrine neoplasia type 2A mutation. PNAS 94 3330-3335.

Mitsiades CS, Mitsiades NS, McMullan CJ, Poulaki V, Shringarpure R, Akiyama M, Hideshima T, Chauhan D, Joseph M, Libermann TA et al. 2004 Inhibition of the insulin-like growth factor receptor-1 tyrosine kinase activity as a therapeutic strategy for multiple myeloma, other hematologic malignancies, and solid tumors. Cancer Cell 5 221-230.

Mitsiades CS, Kotoula V, Poulaki V, Sozopoulos E, Negri J, Charalambous E, Fanourakis G, Voutsinas G, Tseleni-Balafouta S \& Mitsiades N 2006 $a$ Epidermal growth factor receptor as a therapeutic target in human thyroid carcinoma: mutational and functional analysis. Journal of Clinical Endocrinology and Metabolism 91 $3662-3666$

Mitsiades CS, McMillin D, Kotoula V, Poulaki V, McMullan C, Negri J, Fanourakis G, Tseleni-Balafouta S, Ain KB \& Mitsiades N 2006b Antitumor effects of the proteasome inhibitor bortezomib in medullary and anaplastic thyroid carcinoma cells in vitro. Journal of Clinical Endocrinology and Metabolism 91 4013-4021.

Moley JF, Brother MB, Wells SA, Spengler BA, Biedler JL \& Brodeur GM 1991 Low frequency of ras gene mutations in neuroblastomas, pheochromocytomas, and medullary thyroid cancers. Cancer Research 51 1596-1599.

Montani M, Schmitt AM, Schmid S, Locher T, Saremaslani P, Heitz PU, Komminoth P \& Perren A 2005 No mutations but an increased frequency of SDHx polymorphisms in patients with sporadic and familial medullary thyroid carcinoma. Endocrine-Related Cancer 12 1011-1016.

Montero-Conde C, Ruiz-Llorente S, González-Albarran O, Landa I, Pita G, Milne R, Leskelä S, López-Jiménez E, Urioste M, Letón R et al. 2007 Identification of a candidate chromosomal region using a SNP linkage panel suggests a second locus responsible for non-RET MEN2 families. Hormone Research 68 6-7.

Mulligan LM, Gardner E, Smith BA, Mathew CG \& Ponder BA 1993 Genetic events in tumour initiation and progression in multiple endocrine neoplasia type 2. Genes, Chromosomes and Cancer 6 166-177.

Nakagawa T, Mabry M, de Bustros A, Ihle JN, Nelkin BD \& Baylin SB 1987 Introduction of v-Ha-ras oncogene induces differentiation of cultured human medullary thyroid carcinoma cells. PNAS $\mathbf{8 4}$ 5923-5927.

Niccoli-Sire P, Murat A, Rohmer V, Franc S, Chabrier G, Baldet L, Maes B, Savagner F, Giraud S, Bezieau S et al. 2001 Familial medullary thyroid carcinoma with noncysteine ret mutations: phenotypegenotype relationship in a large series of patients. Journal of Clinical Endocrinology and Metabolism 86 3746-3753.

Paes JE \& Ringel MD 2008 Dysregulation of the phosphatidylinositol 3-kinase pathway in thyroid neoplasia. Endocrinology and Metabolism Clinics of North America 37 375-387 (viii-ix).

Park MS, Rosai J, Nguyen HT, Capodieci P, Cordon-Cardo C \& Koff A 1999 p27 and $\mathrm{Rb}$ are on overlapping pathways suppressing tumorigenesis in mice. PNAS 96 6382-6387.

Parthasarathy R, Cote GJ \& Gagel RF 1999 Hammerhead ribozymemediated inactivation of mutant RET in medullary thyroid carcinoma. Cancer Research 59 3911-3914.

Pavelić K, Dedivitis RA, Kapitanović S, Cacev T, Guirado CR, Danić D, Radosević S, Brkić K, Pegan B, Krizanac S et al. 2006 Molecular genetic alterations of FHIT and p53 genes in benign and malignant thyroid gland lesions. Mutation Research 599 45-57. 
Pellegata NS, Quintanilla-Martinez L, Siggelkow H, Samson E, Bink K, Höfler H, Fend F, Graw J \& Atkinson MJ 2006 Germ-line mutations in p27Kipl cause a multiple endocrine neoplasia syndrome in rats and humans. PNAS 103 15558-15563.

Pierchala BA, Tsui CC, Milbrandt J \& Johnson EM 2007 NGF augments the autophosphorylation of Ret via inhibition of ubiquitindependent degradation. Journal of Neurochemistry 100 1169-1176.

Pierotti MA \& Greco A 2006 Oncogenic rearrangements of the NTRK1/NGF receptor. Cancer Letters 232 90-98.

Plaza Menacho I, Koster R, van der Sloot AM, Quax WJ, Osinga J, van der Sluis T, Hollema H, Burzynski GM, Gimm O, Buys CH et al. 2005 RET-familial medullary thyroid carcinoma mutants Y791F and S891A activate a Src/JAK/STAT3 pathway, independent of glial cell line-derived neurotrophic factor. Cancer Research 65 1729-1737.

Plaza-Menacho I, van der Sluis T, Hollema H, Gimm O, Buys CH, Magee AI, Isacke CM, Hofstra RM \& Eggen BJ 2007 Ras/ERK1/ 2-mediated STAT3 Ser727 phosphorylation by familial medullary thyroid carcinoma-associated RET mutants induces full activation of STAT3 and is required for c-fos promoter activation, cell mitogenicity, and transformation. Journal of Biological Chemistry 282 6415-6424.

Qiao S, Iwashita T, Furukawa T, Yamamoto M, Sobue G \& Takahashi M 2001 Differential effects of leukocyte common antigen-related protein on biochemical and biological activities of RET-MEN2A and RET-MEN2B mutant proteins. Journal of Biological Chemistry 276 9460-9467.

Rangarajan A \& Weinberg RA 2003 Opinion: comparative biology of mouse versus human cells: modelling human cancer in mice. Nature Reviews. Cancer 3 952-959.

Robledo M, Gil L, Pollán M, Cebrián A, Ruíz S, Azañedo M, Benitez J, Menárguez J \& Rojas JM 2003 Polymorphisms G691S/S904S of RET as genetic modifiers of MEN 2A. Cancer Research 63 $1814-1817$.

Ruiz-Llorente S, Montero-Conde C, Milne RL, Moya CM, Cebrián A, Letón R, Cascón A, Mercadillo F, Landa I, Borrego S et al. 2007 Medullary Thyroid Carcinoma Clinical Group. Association study of 69 genes in the ret pathway identifies low-penetrance loci in sporadic medullary thyroid carcinoma. Cancer Research 67 9561-9567.

Salmena L, Carracedo A \& Pandolfi PP 2008 Tenets of PTEN tumor suppression. Cell 133 403-414.

Santoro M \& Carlomagno F 2006 Drug insight: small-molecule inhibitors of protein kinases in the treatment of thyroid cancer. Nature Clinical Practice. Endocrinology and Metabolism 2 42-52.

Schagdarsurengin U, Gimm O, Dralle H, Hoang-Vu C \& Dammann R $2006 \mathrm{CpG}$ island methylation of tumor-related promoters occurs preferentially in undifferentiated carcinoma. Thyroid 16 633-642.

Schlumberger M, Carlomagno F, Baudin E, Bidart JM \& Santoro M 2008 New therapeutic approaches to treat medullary thyroid carcinoma. Nature Clinical Practice. Endocrinology and Metabolism 4 22-32.

Schubbert S, Shannon K \& Bollag G 2007 Hyperactive Ras in developmental disorders and cancer. Nature Reviews. Cancer 7 295-308.

Schulz N, Propst F, Rosenberg MP, Linnoila RI, Paules RS, Kovatch R, Ogiso Y \& Vande Woude G 1992 Pheochromocytomas and C-cell thyroid neoplasms in transgenic c-mos mice: a model for the human multiple endocrine neoplasia type 2 syndrome. Cancer Research $\mathbf{5 2}$ $450-455$.

Segouffin-Cariou C \& Billaud M 2000 Transforming ability of MEN2A-RET requires activation of the phosphatidylinositol 3-kinase/AKT signaling pathway. Journal of Biological Chemistry 275 3568-3576.

Sheikh HA, Tometsko M, Niehouse L, Aldeeb D, Swalsky P, Finkelstein S, Barnes EL \& Hunt JL 2004 Molecular genotyping of medullary thyroid carcinoma can predict tumor recurrence.

American Journal of Surgical Pathology 28 101-106.
Sherman SI 2008 Early clinical studies of novel therapies for thyroid cancers. Endocrinology and Metabolism Clinics of North America $\mathbf{3 7}$ 511-524 (xi).

Sipple JH 1961 The association of pheochromocytoma with carcinoma of the thyroid gland. American Journal of Medicine 31 163-166.

Sjöblom T 2008 Systematic analyses of the cancer genome: lessons learned from sequencing most of the annotated human proteincoding genes. Current Opinion in Oncology 20 66-71.

Skinner MA, Moley JA, Dilley WG, Owzar K, Debenedetti MK \& Wells SA Jr 2005 Prophylactic thyroidectomy in multiple endocrine neoplasia type 2A. New England Journal of Medicine $\mathbf{3 5 3}$ 1105-1113.

Smith-Hicks CL, Sizer KC, Powers JF, Tischler AS \& Costantini F 2000 C-cell hyperplasia, pheochromocytoma and sympathoadrenal malformation in a mouse model of multiple endocrine neoplasia type 2B. EMBO Journal 19 612-622.

Sobrinho-Simões M, Máximo V, Rocha AS, Trovisco V, Castro P, Preto A, Lima J \& Soares P 2008 Intragenic mutations in thyroid cancer. Endocrinology and Metabolism Clinics of North America $\mathbf{3 7}$ 333-362 (viii).

van Staveren WC, Solís DW, Delys L, Venet D, Cappello M, Andry G, Dumont JE, Libert F, Detours V \& Maenhaut C 2006 Gene expression in human thyrocytes and autonomous adenomas reveals suppression of negative feedbacks in tumorigenesis. PNAS 103 413-418.

Takahashi C, Contreras B, Iwanaga T, Takegami Y, Bakker A, Bronson RT, Noda M, Loda M, Hunt JL \& Ewen ME 2006 Nras loss induces metastatic conversion of Rbl-deficient neuroendocrine thyroid tumor. Nature Genetics 38 118-123.

Taketomi T, Yoshiga D, Taniguchi K, Kobayashi T, Nonami A, Kato R, Sasaki M, Sasaki A, Ishibashi H, Moriyama M et al. 2005 Loss of mammalian Sprouty2 leads to enteric neuronal hyperplasia and esophageal achalasia. Nature Neuroscience 8 855-857.

Trimarchi JM \& Lees JA 2002 Sibling rivalry in the E2F family. Nature Reviews. Molecular Cell Biology 3 11-20.

Tsui-Pierchala BA, Milbrandt J \& Johnson EM Jr 2002 NGF utilizes c-Ret via a novel GFL-independent, inter-RTK signaling mechanism to maintain the trophic status of mature sympathetic neurons. Neuron 33 261-273.

Vanhorne JB, Andrew SD, Harrison KJ, Taylor SA, Thomas B, McDonald TJ, Ainsworth PJ \& Mulligan LM 2005 A model for GFR alpha 4 function and a potential modifying role in multiple endocrine neoplasia 2. Oncogene 24 1091-1097.

van Veelen W, van Gasteren CJ, Acton DS, Franklin DS, Berger R, Lips CJ \& Höppener JW 2008 Synergistic effect of oncogenic RET and loss of p18 on medullary thyroid carcinoma development. Cancer Research 68 1329-1337.

van Veelen W, Klompmaker R, Gloerich M, van Gasteren CJ, Kalkhoven E, Berger R, Lips CJ, Medema RH, Höppener JW \& Acton DS 2009 P18 is a tumor suppressor gene involved in human medullary thyroid carcinoma and pheochromocytoma development. International Journal of Cancer 124 339-345.

Weber F \& Eng C 2005 Editorial: germline variants within RET: clinical utility or scientific playtoy? Journal of Clinical Endocrinology and Metabolism 90 6334-6336.

Wellbrock C, Karasarides M \& Marais R 2004 The RAF proteins take centre stage. Nature Reviews. Molecular Cell Biology 5 875-885.

Wells SA \& Nevins JR 2004 Evolving strategies for targeted cancer therapy - past, present, and future. Journal of the National Cancer Institute 96 980-981.

Williams BO, Remington L, Albert DM, Mukai S, Bronson RT \& Jacks T 1994 Cooperative tumorigenic effects of germline mutations in $\mathrm{Rb}$ and p53. Nature Genetics 7 480-484.

Wood LD, Parsons DW, Jones S, Lin J, Sjöblom T, Leary RJ, Shen D, Boca SM, Barber T, Ptak J et al. 2007 The genomic landscapes of human breast and colorectal cancers. Science $\mathbf{3 1 8}$ 1108-1113. 
Wu G, Mambo E, Guo Z, Hu S, Huang X, Gollin SM, Trink B, Ladenson PW, Sidransky D \& Xing M 2005 Uncommon mutation, but common amplifications, of the PIK3CA gene in thyroid tumors. Journal of Clinical Endocrinology and Metabolism 90 4688-4693.

Xing M 2005 BRAF mutation in thyroid cancer. Endocrine-Related Cancer 12 245-262.

Yamasaki L, Bronson R, Williams BO, Dyson NJ, Harlow E \& Jacks T 1998 Loss of E2F-1 reduces tumorigenesis and extends the lifespan of $\mathrm{Rbl}(+/-)$ mice. Nature Genetics $\mathbf{1 8}$ 360-364.

Yang KP, Samaan NA, Liang YF \& Castillo SG 1992 Role of insulin-like growth factor-I in the autocrine regulation of cell growth in TT human medullary thyroid carcinoma cells. Henry Ford Hospital Medical Journal 40 293-295.

Ye L, Santarpia L, Cote GJ, El-Naggar AK \& Gagel RF 2008 High resolution array-comparative genomic hybridization profiling reveals deoxyribonucleic acid copy number alterations associated with medullary thyroid carcinoma. Journal of Clinical Endocrinology and Metabolism 93 4367-4372.
Yoshimoto K, Iwahana H, Fukuda A, Sano T, Saito S \& Itakura M 1992 Role of p53 mutations in endocrine tumorigenesis: mutation detection by polymerase chain reaction-single strand conformation polymorphism. Cancer Research 52 5061-5064.

Yuan TL \& Cantley LC 2008 PI3K pathway alterations in cancer: variations on a theme. Oncogene 27 5497-5510.

Zatelli MC, Piccin D, Tagliati F, Bottoni A, Luchin A \& degli Uberti EC 2005 SRC homology-2-containing protein tyrosine phosphatase-1 restrains cell proliferation in human medullary thyroid carcinoma. Endocrinology 146 2692-2698.

Zbuk KM \& Eng C 2007 Cancer phenomics: RET and PTEN as illustrative models. Nature Reviews. Cancer 7 35-45.

Ziebold U, Lee EY, Bronson RT \& Lees JA 2003 E2F3 loss has opposing effects on different pRB-deficient tumors, resulting in suppression of pituitary tumors but metastasis of medullary thyroid carcinomas. Molecular and Cellular Biology 23 6542-6552.

Received in final form 9 April 2009

Accepted 21 April 2009

Made available online as an Accepted Preprint 21 April 2009 